\title{
Effects of Plant Growth Substances on Biomass and Lipid Production in Diatoms
}

\author{
Zhiguo Ju, Lixiao Ding, Kangjun Li, Zhen Ding, Qingna Zhang, and Yuan Li
}

\begin{abstract}
The effects of plant growth stimulating substances like naphthalene-acetic acid (NAA), Gibberellic acid $3\left(\mathbf{G A}_{3}\right)$ and 6-benzylaminopurine (6-BA), or plant growth inhibiting substances like abscisic Acid (ABA) and [(2-chloroethyl) trimethylammonium chloride] (CCC), or their combinations, on biomass and lipid production in Pinnularia gibba var. linearis and Chaetoceros gracilis were studied. When applied at day 1 (stage I), treatments with NAA, GA 3 and 6-BA or their combinations enhanced biomass production but reduced lipid contents. The total lipids, however, were higher in these treatments than that in the control. 6-BA was more effective in stimulating total lipid production. No difference was found among the treatments with $\mathrm{NAA}, \mathrm{GA}_{3}$ or their combination. Adding NAA or $\mathrm{GA}_{3}$ to 6-BA did not enhance biomass or lipid production compared with 6-BA alone. When applied at day 4 (stage II), growth stimulating substances increased biomass production compared with the control but did not affect total lipid production. Less biomass was obtained when the treatments were applied at day 4 compared with that applied at day 1. Treatments with growth inhibitors like $\mathrm{ABA}, \mathrm{CCC}$ or $\mathrm{ABA}+\mathrm{CCC}$ at day 1 reduced biomass production and total lipids, although lipid contents were increased by the treatments. When treated with $\mathrm{ABA}, \mathrm{CCC}$ and $\mathrm{ABA}+\mathrm{CCC}$ at day 4 , however, they did not reduce biomass production while increased lipid contents and total lipids.
\end{abstract}

Index Terms-Plant growth regulator biomass lipids micro algae diatoms.

\section{INTRODUCTION}

Oil or lipids produced by algae has been used as an important source for biodiesel production [1], [2]. To achieve optimal oil production in algae, different approaches have been tested and used, which includes (1) Select species of algae with desirable characteristics of growth, robustness, and high lipid production; (2) Develop ideal cultural conditions that could maximize lipid production; (3) Identify metabolic pathways and key enzymes or genes that involved in lipid biosynthesis; and (4) Create new species based on the understanding on the key enzymes and genes by using molecular biology and technology.

Algae are autotrophic organisms and photosynthetic like plants [3]. It has been suggested that algae might have similar biochemical systems as higher plants and their growth and development is regulated by endogenously produced growth substances [4]-[7] and minerals [8]-[10]. How exogenous plant hormones or growth regulators affect algae growth and lipid production, however, is not clear.

Manuscript received May 18, 2013. This work was supported in part by the Natural Science Foundation of Shandong Province, China.

The authors are with Rizhao Polytechnic College, Shandong Province, China (e-mail: tanggufusang@163.com; lixiaoding65@163.com; kangjunli@163.com; needf@163.com; 2wgt@163.com; angelalee123@163.com; ).
Early study [9], [10] showed that the growth of diatoms like Pinnularia gibba var. linearis or Chaetoceros gracilis had two phases, a log phase (about 3 days in culture, stage I) with a linear increase in biomass production and a stable phase with no significant increase in biomass (stage II). How exogenous growth substances affect biomass and lipid production during these two stages, however, has not been studied. Here we report our study on this approach using Pinnularia gibba var. linearis and Chaetoceros gracilis.

\section{MATERIALS AND METHODS}

\section{A. Strain of Pinnularia gibba var. linearis and Chaetoceros gracilis}

Strain of Pinnularia gibba var. linearis and Chaetoceros gracilis were collected from the seashore 40 mile north of Seattle. A strain with higher neutral lipid production rate was separated and prepared for experiment as described earlier [9], [10].

\section{B. Cultural Conditions}

Basic solution: Strain of Pinnularia gibba var. linearis or Chaetoceros gracilis was cultured in a basic sea water solution at $25^{\circ} \mathrm{C}, 12 \mathrm{D} / 12 \mathrm{~L}$ light period with a light intensity at 3500-4000lx except indicated. The cultural solution contained: sea water, $\mathrm{NaHCO}_{3} \quad 0.15 \mathrm{~g} / \mathrm{L}$, $\mathrm{Na}_{2} \mathrm{SiO}_{3}\left(9 \mathrm{H}_{2} \mathrm{O}\right) 0.20 \mathrm{~g} / \mathrm{L}, \mathrm{NaNO}_{3} 1.00 \mathrm{~g} / \mathrm{L}, \mathrm{KH}_{2} \mathrm{PO}_{4} 0.02 \mathrm{~g} / \mathrm{L}$, Vitamin $\mathrm{B}_{1} 2.7 \mathrm{mg} / \mathrm{L}$, and Vitamin $\mathrm{B}_{12} 1.5 \mu \mathrm{g} / \mathrm{L}$.

\section{Treatments}

\section{1) Growth promoting solution}

Strain was incubated in basic solution with NAA, $\mathrm{GA}_{3}$, 6-BA, NAA $+\mathrm{GA}_{3}, \mathrm{NAA}+6-\mathrm{BA}, \mathrm{GA}_{3}+6-\mathrm{BA}$, and NAA + $\mathrm{GA}_{3}+6-\mathrm{BA}$ respectively. For each regulator, a concentration range from 1 to $20 \mu \mathrm{mol} / \mathrm{L}$ was tested and the optimum concentrations were used for comparison, which were: NAA $15 \mu \mathrm{mol} / \mathrm{L}, \mathrm{GA}_{3} 10 \mu \mathrm{mol} / \mathrm{L}$, and 6-BA $10 \mu \mathrm{mol} / \mathrm{L}$. For the combinations, half of the optimum concentration was used in two-regulator combinations and one third was used in the three-regulator combination.

\section{2) Growth inhibiting solution}

Strain was incubated in basic solution with ABA,CCC and $\mathrm{ABA}+\mathrm{CCC}$, respectively. For each regulator, a concentration range from 10 to $200 \mu \mathrm{mol} / \mathrm{L}$ was tested and the optimum concentration was ABA $15 \mu \mathrm{mol} / \mathrm{L}$ and CCC 50 $\mu \mathrm{mol} / \mathrm{L}$. For the combination, half of the optimum concentration was used for each inhibitor.

\section{3) Application time treatments}

Growth promoting or inhibiting solutions were prepared separately as above and added to the incubation solution 
either at day 1 (stage I), or at day 4 (end of log phase in growth, stage II), respectively. When algae was need to transfer from one solution to another, the algae was washed with sea water first, then added to the new incubation solution.

All treatments were carried out in a self-made 10 L-bioreactor and inoculates were incubated at $25^{\circ} \mathrm{C}$ with 12D/12L light period and a light intensity of 3500-40001x except specifically indicated. Each treatment had 3 replicates. Samples were harvested after 7 days incubation, centrifuged at $6000 \mathrm{r} / \mathrm{min}$ for $10 \mathrm{~min}$, freeze dried, and stored in a freezer for further use.

\section{Biomass Measurement}

The incubation solution was mixed thoroughly, $100 \mathrm{~mL}$ of the solution was centrifuged $6000 \mathrm{r} / \mathrm{min}$., supernatant was discarded and the precipitate was washed with distilled water twice, centrifuged at $6000 \mathrm{r} / \mathrm{min}$. for $10 \mathrm{~min}$., dried in an oven at $80{ }^{\circ} \mathrm{C}$ for $5 \mathrm{hr}$., placed in a desiccator for $10 \mathrm{hr}$. and weighted. The biomass of Pinnularia gibba var. linearis and Chaetoceros gracilis was represented as dry mass (mg D.W./L).

\section{E. Neutral Lipid, Chrysolaminarin and Pectin Measurement}

Neutral lipids were measured as described by Roesller [11]. Chrysolaminarin measurement was carried out by the method of Beattie et al. [8] and the method of Meijer et al. [12] was used to measure pectin.

Data were subjected to analysis of variance (ANOVA) using the SAS Statistical Software (SAS Institute Inc. NC, USA).

\section{RESULTS}

\section{A. Effects of NAA, GA $A_{3}$ and 6-BA or Their Combinations on Biomass and Total Lipid Production When Applied at Day 1}

Compared to the control, NAA, $\mathrm{GA}_{3}$ and 6-BA or their combinations enhanced biomass production, reduced lipid contents, but increased total lipid production in Pinnularia gibba var. linearis (Table I). Cultures containing 6-BA had the highest level of biomass and total lipid among all the treatments. No differences were found among NAA, GA $\mathrm{G}_{3}$ and their combination. Adding $\mathrm{GA}_{3}$ or NAA to 6-BA did not increase biomass or total lipid production compared with 6-BA alone. Results from Chaetoceros gracilis showed similar pattern (Table II).

\section{B. Effects of Application Time of NAA, GA3or 6-BA on Biomass and Total Lipid Production When Applied At Day 4}

When applied at day 4(stage II), all treatments stimulated biomass production,reduced lipid contents, but did not affect total lipid production compared with the control in both Pinnularia gibba var. linearis (Table III) and Chaetoceros gracilis(Table IV). There was no difference among all the treatments on both biomass production and lipid contents. Compared with treatments at day 1 (Table I and II), however, treatments at day 4 were less effective on stimulating biomass production in both Pinnularia gibba var. linearis and Chaetoceros gracilis.
TABLE I: EFFECTS OF NAA, GA 3 AND 6-BA OR THEIR COMBINATIONS APPLIED AT DAY ONE ON BIOMASS AND LIPID PRODUCTION IN PINNULARIA GIBBA VAR. LINEARIS

\begin{tabular}{|c|c|c|c|}
\hline Treatments & $\begin{array}{l}\text { Biomass (mg } \\
\text { D.W/L) }\end{array}$ & $\begin{array}{l}\text { Lipids Content } \\
\text { (mg/g D.W) }\end{array}$ & $\begin{array}{l}\text { Total lipid } \\
(\mathrm{mg} / \mathrm{L})\end{array}$ \\
\hline Control & $37.5 \mathrm{c}$ & $386 a$ & $14.5 \mathrm{c}$ \\
\hline NAA & $58.9 \mathrm{~b}$ & $326 \mathrm{~b}$ & $19.2 \mathrm{~b}$ \\
\hline $\mathrm{GA}_{3}$ & $66.5 \mathrm{ab}$ & $298 \mathrm{~b}$ & $19.8 \mathrm{~b}$ \\
\hline $6-\mathrm{BA}$ & $71.7 \mathrm{a}$ & $338 \mathrm{~b}$ & $24.2 \mathrm{a}$ \\
\hline $\mathrm{NAA}+\mathrm{GA}_{3}$ & $60.2 \mathrm{~b}$ & $319 b$ & $19.2 \mathrm{~b}$ \\
\hline $\mathrm{GA}_{3}+6-\mathrm{BA}$ & $69.2 \mathrm{a}$ & $331 \mathrm{~b}$ & $22.9 \mathrm{a}$ \\
\hline $\mathrm{NAA}+6-\mathrm{BA}$ & $68.1 \mathrm{a}$ & $327 \mathrm{~b}$ & $22.2 \mathrm{a}$ \\
\hline $\mathrm{NAA}+\mathrm{GA}_{3}+6-\mathrm{BA}$ & $72.1 \mathrm{a}$ & $332 \mathrm{~b}$ & $23.9 \mathrm{a}$ \\
\hline ANOVA & $*$ & $*$ & * \\
\hline
\end{tabular}

*: significant difference at $\mathrm{p} \leq 0.05$ level. ns: not significant.

TABLE II: EFFECTS OF NAA, GA 3 AND 6-BA OR THEIR COMBINATIONS APPLIED AT DAY ONE ON BIOMASS AND LIPID PRODUCTION IN CHAETOCEROS GRACILIS

\begin{tabular}{llll}
\hline \hline Treatments & $\begin{array}{l}\text { Biomass }(\mathrm{mg} \\
\mathrm{D} . \mathrm{W} / \mathrm{L})\end{array}$ & $\begin{array}{l}\text { Lipids Content } \\
(\mathrm{mg} / \mathrm{g} \text { D.W })\end{array}$ & $\begin{array}{l}\text { Total lipid } \\
(\mathrm{mg} / \mathrm{L})\end{array}$ \\
\hline Control & $36.8 \mathrm{c}$ & $418 \mathrm{a}$ & $15.4 \mathrm{c}$ \\
$\mathrm{NAA}$ & $50.1 \mathrm{~b}$ & $333 \mathrm{~b}$ & $18.9 \mathrm{~b}$ \\
$\mathrm{GA}_{3}$ & $61.4 \mathrm{ab}$ & $314 \mathrm{~b}$ & $16.7 \mathrm{~b}$ \\
$6-\mathrm{BA}$ & $73.1 \mathrm{a}$ & $321 \mathrm{~b}$ & $23.5 \mathrm{a}$ \\
$\mathrm{NAA}+\mathrm{GA}_{3}$ & $56.7 \mathrm{~b}$ & $335 \mathrm{~b}$ & $20.0 \mathrm{~b}$ \\
$\mathrm{GA}_{3}+6-\mathrm{BA}$ & $66.8 \mathrm{a}$ & $318 \mathrm{~b}$ & $21.2 \mathrm{a}$ \\
$\mathrm{NAA}+6-\mathrm{BA}$ & $69.5 \mathrm{a}$ & $309 \mathrm{~b}$ & $21.5 \mathrm{a}$ \\
$\mathrm{NAA}+\mathrm{GA}_{3}+6-\mathrm{BA}$ & $70.9 \mathrm{a}$ & $328 \mathrm{~b}$ & $23.3 \mathrm{a}$ \\
ANOVA & $*$ & $*$ & $*$ \\
\hline
\end{tabular}

*: significant difference at $\mathrm{p} \leq 0.05$ level. ns: not significant.

TABLE III: EFFECTS OF NAA, GA 3 AND 6-BA OR THEIR COMBINATIONS APPLIED AT DAY FOUR ON BIOMASS AND LIPID PRODUCTION IN PINNULARIA GIBBA VAR. LINEARIS

\begin{tabular}{llll}
\hline \hline Treatments & $\begin{array}{l}\text { Biomass }(\mathrm{mg} \\
\mathrm{D} . \mathrm{W} / \mathrm{L})\end{array}$ & $\begin{array}{l}\text { Lipids Content } \\
(\mathrm{mg} / \mathrm{g} \mathrm{D} . \mathrm{W})\end{array}$ & $\begin{array}{l}\text { Total lipid } \\
(\mathrm{mg} / \mathrm{L})\end{array}$ \\
\hline Control & $35.5 \mathrm{~b}$ & $382 \mathrm{a}$ & $13.6 \mathrm{a}$ \\
$\mathrm{NAA}$ & $47.2 \mathrm{a}$ & $279 \mathrm{~b}$ & $13.2 \mathrm{a}$ \\
$\mathrm{GA}_{3}$ & $45.6 \mathrm{a}$ & $269 \mathrm{~b}$ & $12.3 \mathrm{a}$ \\
$6-\mathrm{BA}$ & $47.7 \mathrm{a}$ & $291 \mathrm{~b}$ & $13.9 \mathrm{a}$ \\
$\mathrm{NAA}+\mathrm{GA}_{3}$ & $43.6 \mathrm{a}$ & $276 \mathrm{~b}$ & $12.0 \mathrm{a}$ \\
$\mathrm{GA}_{3}+6-\mathrm{BA}$ & $44.3 \mathrm{a}$ & $284 \mathrm{~b}$ & $12.6 \mathrm{a}$ \\
$\mathrm{NAA}+6-\mathrm{BA}$ & $45.2 \mathrm{a}$ & $290 \mathrm{~b}$ & $13.1 \mathrm{a}$ \\
$\mathrm{NAA}+\mathrm{GA}+6-\mathrm{BA}$ & $42.8 \mathrm{a}$ & $282 \mathrm{~b}$ & $12.1 \mathrm{a}$ \\
$\mathrm{ANOVA}$ & $*$ & $*$ & $\mathrm{~ns}$ \\
\hline \hline
\end{tabular}

*: significant difference at $\mathrm{p} \leqslant 0.05$ level. ns: not significant.

TABLE IV: EFFECTS OF NAA, GA 3 AND 6-BA OR THEIR COMBINATIONS APPLIED AT DAY ONE ON BIOMASS AND LIPID PRODUCTION IN CHAETOCEROS GRACILIS

\begin{tabular}{llll}
\hline \hline Treatments & $\begin{array}{l}\text { Biomass }(\mathrm{mg} \\
\mathrm{D} . \mathrm{W} / \mathrm{L})\end{array}$ & $\begin{array}{l}\text { Lipids Content } \\
(\mathrm{mg} / \mathrm{g} \text { D.W })\end{array}$ & $\begin{array}{l}\text { Total lipid } \\
(\mathrm{mg} / \mathrm{L})\end{array}$ \\
\hline Control & $34.3 \mathrm{~b}$ & $431 \mathrm{a}$ & $14.8 \mathrm{a}$ \\
$\mathrm{NAA}$ & $43.2 \mathrm{a}$ & $305 \mathrm{~b}$ & $13.2 \mathrm{a}$ \\
$\mathrm{GA}_{3}$ & $41.7 \mathrm{a}$ & $325 \mathrm{~b}$ & $13.6 \mathrm{a}$ \\
$6-\mathrm{BA}$ & $45.2 \mathrm{a}$ & $321 \mathrm{~b}$ & $14.5 \mathrm{a}$ \\
$\mathrm{NAA}+\mathrm{GA}_{3}$ & $41.6 \mathrm{a}$ & $323 \mathrm{~b}$ & $13.4 \mathrm{a}$ \\
$\mathrm{GA}_{3}+6-\mathrm{BA}$ & $46.1 \mathrm{a}$ & $331 \mathrm{~b}$ & $15.3 \mathrm{a}$ \\
$\mathrm{NAA}+6-\mathrm{BA}$ & $44.8 \mathrm{a}$ & $333 \mathrm{~b}$ & $14.9 \mathrm{a}$ \\
$\mathrm{NAA}+\mathrm{GA}_{3}+6-\mathrm{BA}$ & $45.3 \mathrm{a}$ & $318 \mathrm{~b}$ & $14.4 \mathrm{a}$ \\
ANOVA & $*$ & $*$ & $\mathrm{~ns}$ \\
\hline \hline
\end{tabular}

*: significant difference at $\mathrm{p} \leqslant 0.05$ level. ns: not significant. 


\section{Effects of Growth Inhibitors on Biomass and Total Lipid Production When Applied at Day 1}

When applied at Day 1(stage I), no difference in biomass and lipid content was found among treatments with ABA, $\mathrm{CCC}$ or their combination (Table 5). All treatments reduced biomass production, increased lipid contents compared with the control. Total lipids in these treatments, however, were similar to the control. Trends were similar between Pinnularia gibba var. linearis and Chaetoceros gracilis (Table 6).

\section{Effects of Growth Inhibitors on Biomass and Total Lipid Production When Applied at Day 4}

When applied at day 4(stage II), no difference was found among treatments with ABA, CCC and their combinations in Pinnularia gibba var. linearis. Therefore, pooled data were used for comparison between regulators applied at day 1 and day 4. Inhibitors applied at day 1 (stage I) reduced biomass and total lipid production, although their lipid contents were higher (Table II). When applied at day 4 (stage II), however, inhibitors did not affect biomass production, but increased lipid contents and total lipids compared to the control. Inhibitors applied at day 4 significantly increased total lipid production compared with inhibitors applied at day 1. Results from Chaetoceros gracilis showed similar pattern (Data not shown).

\section{E. Effects of a Combination of Growth Stimulators and Inhibitors on Biomass and Total Lipid Production}

When 6-BA applied at day 1 and ABA or CCC applied at day 4, treatments increased biomass production, lipid contents, and total lipid production compared with both control or 6-BA, ABA, CCC alone in Pinnularia gibba var. linearis (Table VIII). No difference was found among treatments between $\mathrm{ABA}$ and $\mathrm{CCC}$. The combination of 6-BA applied at day 1 plus ABA (or CCC) at day 4 produced maximum total lipids. Results from Chaetoceros gracilis showed similar pattern (Data not shown).

TABLE V: EFFECTS OF ABA, CCC AND THEIR COMBINATIONS APPLIED AT DAY 1 ON BIOMASS AND LIPID PRODUCTION IN PINNULARIA GIBBA VAR.

\begin{tabular}{llll}
\hline \multicolumn{4}{c}{ LINEARIS } \\
\hline Treatments & $\begin{array}{l}\text { Biomass }(\mathrm{mg} \\
\mathrm{D} . \mathrm{W} / \mathrm{L})\end{array}$ & $\begin{array}{l}\text { Lipids Content } \\
(\mathrm{mg} / \mathrm{g} \text { D.W })\end{array}$ & $\begin{array}{l}\text { Total lipid } \\
(\mathrm{mg} / \mathrm{L})\end{array}$ \\
\hline Control & $35.2 \mathrm{a}$ & $365 \mathrm{~b}$ & $15.4 \mathrm{a}$ \\
ABA & $16.9 \mathrm{~b}$ & $473 \mathrm{a}$ & $8.0 \mathrm{~b}$ \\
CCC & $19.8 \mathrm{~b}$ & $437 \mathrm{a}$ & $8.7 \mathrm{~b}$ \\
ABA + CCC & $17.7 \mathrm{~b}$ & $468 \mathrm{a}$ & $8.3 \mathrm{~b}$ \\
ANOVA & $*$ & $*$ & $*$ \\
\hline \hline
\end{tabular}

*: significant difference at $\mathrm{p} \leqslant 0.05$ level. ns: not significant.

TABLE VI: EFFECTS OF ABA, CCC AND THEIR COMBINATIONS APPLIED AT DAY 1 ON BIOMASS AND LIPID PRODUCTION IN CHAETOCEROS GRACILIS

\begin{tabular}{llll}
\hline \hline Treatments & $\begin{array}{l}\text { Biomass }(\mathrm{mg} \\
\text { D.W/L) }\end{array}$ & $\begin{array}{l}\text { Lipids Content } \\
(\mathrm{mg} / \mathrm{g} \mathrm{D} . \mathrm{W})\end{array}$ & $\begin{array}{l}\text { Total lipid } \\
(\mathrm{mg} / \mathrm{L})\end{array}$ \\
\hline Control & $42.1 \mathrm{a}$ & $419 \mathrm{~b}$ & $17.6 \mathrm{a}$ \\
$\mathrm{ABA}$ & $20.3 \mathrm{~b}$ & $468 \mathrm{a}$ & $9.5 \mathrm{~b}$ \\
$\mathrm{CCC}$ & $22.7 \mathrm{~b}$ & $472 \mathrm{a}$ & $10.7 \mathrm{~b}$ \\
$\mathrm{ABA}+\mathrm{CCC}$ & $18.2 \mathrm{~b}$ & $481 \mathrm{a}$ & $8.8 \mathrm{~b}$ \\
ANOVA & $*$ & $*$ & $*$ \\
\hline \hline
\end{tabular}

*: significant difference at $\mathrm{p} \leqslant 0.05$ level. ns: not significant.
TABLE VII: EFFECTS OF APPLICATION TIMING FOR GROWTH INHIBITORS ON BIOMASS AND LiPID PRODUCTION (POOLED DATA) IN PINNULARIA GIBBA VAR. LINEARIS

\begin{tabular}{llll}
\hline \hline Treatments & $\begin{array}{l}\text { Biomass }(\mathrm{mg} \\
\mathrm{D} . \mathrm{W} / \mathrm{L})\end{array}$ & $\begin{array}{l}\text { Lipids Content } \\
(\mathrm{mg} / \mathrm{g} \text { D.W })\end{array}$ & $\begin{array}{l}\text { Total lipid } \\
(\mathrm{mg} / \mathrm{L})\end{array}$ \\
\hline Control & $42.1 \mathrm{a}$ & $372 \mathrm{~b}$ & $15.7 \mathrm{~b}$ \\
Inhibitor (day one) & $18.1 \mathrm{~b}$ & $459 \mathrm{a}$ & $8.3 \mathrm{c}$ \\
Inhibitor (day four) & $41.2 \mathrm{a}$ & $438 \mathrm{a}$ & $18.0 \mathrm{a}$ \\
ANOVA & $*$ & $*$ & $*$ \\
\hline \hline
\end{tabular}

*: significant difference at $\mathrm{p} \leqslant 0.05$ level. ns: not significant.

TABLE VIII: EFFECTS OF STIMULATOR AND INHIBITOR COMBINATION ON BIOMASS AND LIPID PRODUCTION (POOLED DATA) IN PINNULARIA GIBBA VAR. LINEARIS

\begin{tabular}{llll}
\hline \hline Treatments & $\begin{array}{l}\text { Biomass }(\mathrm{mg} \\
\text { D.W/L) }\end{array}$ & $\begin{array}{l}\text { Lipids Content } \\
(\mathrm{mg} / \mathrm{g} \mathrm{D} . \mathrm{W})\end{array}$ & $\begin{array}{l}\text { Total lipid } \\
(\mathrm{mg} / \mathrm{L})\end{array}$ \\
\hline Control & $38.4 \mathrm{c}$ & $387 \mathrm{c}$ & $14.9 \mathrm{c}$ \\
6-BA(day 1) & $69.2 \mathrm{a}$ & $279 \mathrm{~d}$ & $19.3 \mathrm{~b}$ \\
ABA(day 4) & $19.8 \mathrm{~d}$ & $487 \mathrm{a}$ & $19.6 \mathrm{~b}$ \\
CCC(day 4) & $21.2 \mathrm{~d}$ & $479 \mathrm{a}$ & $19.2 \mathrm{~b}$ \\
6-BA(day & $60.3 \mathrm{~b}$ & $403 \mathrm{~b}$ & $24.3 \mathrm{a}$ \\
1)+ABA(day 4) & & & $23.8 \mathrm{a}$ \\
6-BA(day & $58.3 \mathrm{~b}$ & $409 \mathrm{~b}$ & \\
1)+CCC(day 4) & & $*$ & $*$ \\
ANOVA & $*$ & $*$ & \\
\hline \hline
\end{tabular}

*: significant difference at $\mathrm{p} \leqslant 0.05$ level. ns: not significant.

\section{DISCUSSION}

Plant growth substances play an important role in algae growth [4]-[6]. How these growth regulators affect lipid biosynthesis and accumulation in diatoms, however, has not been studied. Our results showed that the growth promoting (NAA, $\mathrm{GA}_{3}, 6-\mathrm{BA}$ and their combinations) and inhibiting substances (ABA, CCC and their combination) displayed different roles on biomass and total lipid production in both Pinnularia gibba var. linearis and Chaetoceros gracilis. The growth stimulating substances enhanced biomass and total lipid production, reduced lipid contents in the treatments compared with that in the control. 6-BA was most effective in stimulating biomass production and lipid accumulation among the 3 growth promoting substances being used. The growth inhibiting substances, however, reduced biomass and total lipid production, while increased lipid contents in the treatments than that in the control.

It has been well documented that growth stimulating substances enhance cell division and enlargement, while growth inhibiting substances inhibit cell division and cell growth [4]-[6]. Our results indicate that the growth stimulating substances enhanced lipid production by increasing biomass production in diatoms. 6-BA was more effective when applied at day 1 than applied at day 4(cells start to mature), indicating early application could be used to increase biomass and lipid yields in diatom culture. Since treatment with these substances reduced lipid contents in cells, however, growth promoting substances may not involved in regulating lipid biosynthesis or accumulation directly.

On the other hand, growth inhibiting substances like ABA and $\mathrm{CCC}$ did not increase total lipid production(majorly because of the reduced biomass), they did enhanced lipid contents, indicating ABA or CCC treatment may involved in 
regulating lipid biosynthesis or accumulation process. When applied at day $1, \mathrm{ABA}, \mathrm{CCC}$ or $\mathrm{ABA}+\mathrm{CCC}$ reduced biomass and total lipid production. When applied at day 4 , however, these treatments increased lipid content without affecting biomass production, resulted higher total lipid production, further confirmed that ABA or CCC may involve in regulating lipid biosynthesis or accumulation.

Since stage $I$ is the period for active cell division and growth and stage II is the period of cell maturation in Pinnularia gibba var. linearis or Chaetoceros gracilis ${ }^{[9,10]}$, it is understandable that growth promoting substances like 6-BA were more effective in increasing biomass production when applied at day 1, while applying growth inhibiting substances like ABA or CCC at day 4 were more effective in stimulating lipid production without affecting biomass production in diatoms . And the most effective treatment to stimulate total lipid production, therefore, is the combination of 6-BA and ABA (or CCC) at different stages(Table 8). While 6-BA treatment applied at day 1 produce total lipid of $19.3 \mathrm{mg} / \mathrm{L}, \mathrm{ABA}$ treatment applied at day 4 produced total lipid of $19.6 \mathrm{mg} / \mathrm{L}$, a combination of 6-BA at day 1 and ABA (or CCC) at day 4 treatment produced about $23-24 \mathrm{mg} / \mathrm{L}$ of total lipid, indicating a very promising approach to increase total lipid production in diatoms.

\section{SUMMARY}

Growth promoting substances promote biomass production and reduced lipid content, while growth inhibiting substances reduced biomass production and increased lipid content. A balance between biomass production and lipid content is needed to achieve higher lipid production and a combination of promoting substances applied at early stage (day 1) and inhibiting substances applied at late stage (day 4) resulted higher lipid production in diatoms.

How these treatments affect enzymes and genes that involve in lipid biosynthesis and accumulation in diatoms, however, needs further investigation.

\section{ACKNOWLEDGMENT}

This project was supported by an oversea specialist fund from Shandong government. The authors are in great debt to Dr. Brain Smith for his support in conducting this research.

\section{REFERENCES}

[1] L. Gouveia and A. C. Oliviera, "Microalgae as a raw material for biofuels production," J. Indust. Microbio. Biotech, vol. 36, pp. 269-274. June 2009

[2] J. Sheehan, “A look back at US Department of Energy's Aquatic pecies Program: Biodiesel from algae," National Renewable Lab. Golden Co. vol. 80401 pp. 580-24190, May 1998.

[3] J. E. Graham, L. W. Wilcox, and L. E. Graham, Algae Benjaming Cummings, 2008, pp. 21-79.

[4] P. M. Bradley and D. P. Cheney, "Some effects of plant growth regulators on tissue cultures of the marine red alga Agardhiella subulata (Gigartinales, Rhodophyta)," Hydrobiol, vol. 204, pp. 353-360, July 1990.

[5] P. M. Bradlley, "Plant hormones do have a role in controlling growth and development of algae," J. Phycol,, vol. 27, pp. 317-321, 1991.

[6] L. V.Evans and A. J. Trewavs, "Is algal development controlled by plant growth substances?” J. Phycol, vol. 27, pp. 322-326, Feb. 1991.

[7] I. Puneva, T. Toncheva-Panova, and M. Bozhkova, "Effect of fusarium oxysporum exudate on the Growth and viability of scenedesmus acutus," Bulg. J. Plant physiol., vol. 25, pp. 76-82, Jan. 1999.

[8] J. Beattie, E. L. Hirst, and E. Percival, "Studies on the metabolism of the Chrysophyceae," Biochem J., vol.79, pp. 531-537, Feb.1961.

[9] Z. Ju, L. Ding, F. Zheng, Q. Zhang, and Y. Li., "Effects of silicon, calcium or boron on assimilate allocation in Pinnularia gibba var. Linearis," in Proc.2011 Intern. Agri. Ani. Sci. Conf., vol. 22, pp. 100-104. Dec. 2011.

[10] Z. Ju, L. Ding, Q. Song, Z. Wu, and F.Zheng, "Diatoms as a modle system in studying lipid biosynthesis regulation," Int. J. Environ. Sci. Devel, vol. 2, pp. 493-495. Dec. 2011.

[11] P. G. Roessler, "An Effects of silicon deficiency on lipid composition and metabolism in the diatom Cyclotella cryptica," J. Phycol., vol. 24, pp. 394-400, May 1988.

[12] W. J. M. Meijer, N. Vertregt, B. Rutgers, and M. van de Waart, "The pectin content as a measure of the retting and rettability of flax," Industrial Crops and Products, vol. 4, pp. 273-284, July 1995.

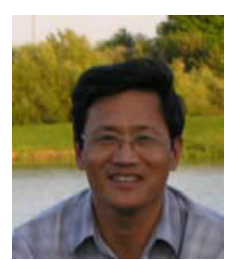

Zhiguo Ju received his bachelor degree from Laiyang Agricultural College, master degree from Beijing University, China and Ph.D from the University of Massachusetts at Amherst, USA. He used to be a Post-Doc at the University of California, Davis, a research scientist at USDA-ARS Tree Fruit Research Lab in Wenatchee, Washington State, and a research scientist at Valent BioScience Corp in Chicago. He was a professor at Laiyang Agricultural College, and currently is a faculty member professor at Rizhao Polytechnic College in China. His interests include plant physiology, postharvest biology and biochemistry, bio-pesticide development, and bio-energy research. 